\begin{tabular}{|c|c|c|}
\hline 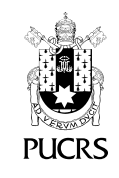 & $\begin{array}{l}\text { ESCOLA DE } \\
\text { HUMANIDADES }\end{array}$ & $\begin{array}{l}\text { Revista Digital do Programa de Pós-Graduação em Letras da PUCRS } \\
\text { Letrônica, Porto Alegre, v. 13, n. 2, p. 1-14, abr.-jun. } 2020 \\
\text { e-ISSN: } 1984-4301\end{array}$ \\
\hline 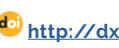 & $\mathrm{rg} / 10.15448 / 1984-4301.2020 .2 .36176$ & \\
\hline
\end{tabular}

\title{
Discursos político-religiosos como armas de guerra: heteroterrorismo em ação contra sexualidades dissidentes
}

\author{
Political-religious discourses as weapons of war: heteroterrorism in action against \\ dissident sexualities
}

\section{Alexandre de Oliveira Fernandes $^{1}$ \\ orcid.org/0000-0002-1556-4373 \\ alexandre.pro@gmail.com}

\section{Luciano Fernandes de \\ Souza ${ }^{3}$}

orcid.org/0000-0002-7466-4577

lucianof5@hotmail.com

Recebido em: 28 out. 2019. Aprovado em: 26 fev. 2020. Publicado em: 13 ago. 2020.
Resumo: Discursos político-religiosos estão implicados na construção de corpos e subjetividades generificadas. Organizando-se como uma arma de guerra, entrelaçam crenças e posicionamentos políticos, impõem padrões de normalidade, enfatizam ou desprezam determinadas condutas, reiterando discursos que seguem a heteronorma. Com vistas à construção de sujeitos e subjetividades normativizados - binários e dimórficos -, tratam o outro como abjeto, uma estratégia prático-discursiva que inferioriza aquele que se quer excluir do humano. Estigmatizando características corporais e psíquicas, legam aos sujeitos desviantes, ares de animalidade e de aberração. Defendemos neste artigo que tal interpelação discursiva emanada por discursos político-religiosos que atuam como armas de guerra, regula desejos, produz privações, punições e inscreve os dissidentes sexuais em uma alteridade cativa e repreendida, sob o signo de um "heteroterrorismo" (BENTO, 2017). Apoiamos nossa argumentação, especialmente em Roland Barthes (2004), Jacques Derrida (2001), Judith Butler (2017), Michel Foucault (2012) e Berenice Bento (2017).

Palavras-chave: Discursos politico-religiosos. Interpelação. Heteroterrorismo.

Abstract: Political-religious discourses are implicated in the construction of bodies and generated subjectivities. Organizing itself as a weapon of war, coming into contact with crimes and political positions, imitating standards of normality, emphasizing or disregarding tests of conduct, reiterating discourses that performs a heteronorm. With a view to the construction of individuals and normative subjectivities - binary and dimorphic -, they treat or as abject a practical-discursive strategy that inferiorizes those who want to exclude the human. Stigmatizing corporate and psychic characteristics according to deviant individuals, animal areas and aberration. We argue in this article that such discursive interpellation emanating from religious-religious discourses acting as weapons of war, rules regulating desires, producing deprivation, punishment and inscribing sexual dissenters in a captive and representative alteration, under or under the sign of "heteroterrorism" (BENTO, 2017). We support our argument, especially in Roland Barthes (2004), Jacques Derrida (2001), Judith Butler (2017), Michel Foucault (2012) e Berenice Bento (2017). Keywords: Discourses. Religion. Interpellation. Heteroterrorism.

\section{Introdução: Do discurso como arma de guerra}

Ensina-nos Judith Butler (2017) que faz sentido rastrear os usos do discurso, entendidos não como um conjunto de palavras, mas como um sistema que estrutura determinado imaginário social, pois estaremos tratando de poder e controle, haja vista que, "em toda sociedade a produção do discurso é ao mesmo tempo controlada, selecionada, organizada e redistribuida por certo número de procedimentos" 
(FOUCAULT, 2012, p. 8). São eles que podem privilegiar direitos civis para homoafetivos, como na Holanda e Canadá, produzindo políticas progressistas e fortalecendo as lutas contra o racismo e a discriminação religiosa ou favorecer política homofóbica e cinicamente autoritária. Logo, buscando compreender como se relacionam os discursos politico-religiosos com as sexualidades desviantes da heteronorma, problematizamos, neste texto, ações/discursos proferidos por políticos cuja atuação é marcada por sua formação religiosa.

No Brasil, país predominantemente judaicocristão ${ }^{3}$, não há que se falar em políticas que contrariem as agruras vividas por homoafetivos, antes, há interesse em regular as disposições afetivas e éticas dos sujeitos, em uma trama que atrela Estado a concepções religiosas.

Eleito em Outubro de 2018, empunhando bandeiras como o antipetismo, o antiesquerdismo comunista, Jair Messias Bolsonaro (PSL), capitão reformado do Exército em cujo slogan de campanha se podia ler "Brasil acima de tudo, Deus acima de todos", ofereceu a estrutura jurídica do Poder Executivo à bancada evangélica da Câmara de Deputados, para que sejam viabilizadas suas propostas por meio de decretos presidenciais. Comprometendo-se a indicar um ministro "terrivelmente evangélico"4 para uma vaga no Supremo Tribunal Federal (STF) e tendo Damares Alves no comando da pasta "Mulher, Familia e Direitos Humanos", o governo não se furta, constantemente, a acenar com afagos à agenda conservadora. Recentemente, seis ministros da presidência almoçaram com a bancada evangélica da Câmara para "debater os rumos do governo e apresentar seus resultados frente às pautas reacionárias desse setor". ${ }^{5}$

Sabemos que "em nenhum momento ou lugar, as religiões deixaram de ser uma "questão de Estado'" (ALMEIDA; MONTEIRO, 2000, p. 326), por outro lado, é nítido o brusco fortalecimento do poder da chamada bancada da Bíblia no Congresso Nacional. Conforme o deputado federal Silas Câmara (Republicanos - AM), coordenador da bancada evangélica - composta por um em cada seis deputados da atual legislatura -, a relação entre o governo e os religiosos caminha de vento em popa: "Nossa prioridade é outra: principios, costumes e defender vida, povo, família. Nisso estamos trabalhando muito bem e nos entendendo muito bem com o governo. Estamos muito bem atendidos no que diz respeito à nossa pauta".

De que pautas se vale o deputado? Daquelas francamente interessadas em educação religiosa cristã nas escolas, tanto quanto em questões econômicas, como por exemplo, manutenção de privilégios fiscais para as igrejas e reformas da previdência e trabalhista. Trata-se de agenda amparada em questões ideológicas e morais, a exemplo do chamado combate à "ideologia de gênero" e ao aborto. ${ }^{6}$

E segue a pauta: a ministra Damares Alves, ex-assessora parlamentar do senador e também pastor Magno Malta (PR) - responsável por projeto de emenda à Constituição (PEC) que demanda a proibição do aborto em casos que já estão previstos em lei7 -, não foi alçada ao ministério sem um complexo jogo de poder político-religioso. Damares conta em seu curriculo ter sido chefe de

\footnotetext{
3 Segundo o Instituto Brasileiro de Geografia e Estatísticas (IBGE), vide o censo de 2010, cerca de 60\% da população professa a religião católica apostólica romana e $22,2 \%$, religiões evangélicas. Todavia, há que se levar em conta o trânsito entre as religiões, até porque. na contemporaneidade, assistimos a continuidades, descontinuidades e transformações no que significa ter uma religiosidade. Como defende Leonel (2010, p. 403) "pesquisas que partirem para o levantamento de números e respectiva análise do campo religioso no Brasil, deverão incluir, entre suas indagações, filtros que permitam captar as dimensões do trânsito religioso dos indivíduos para além das confissões religiosas ou daquilo que se chamaria de conversão clássica". Pode-se conferir também: http://g1.globo.com/brasil/ noticia/2012/06/numero-de-evangelicos-aumenta-61-em-10-anos-aponta-ibge.html. Acesso em: 20 maio 2019.

4 Bolsonaro diz que vai indicar ministro 'terrivelmente evangélico' para o STF. G1. 10 maio 2019. Brasilia. Disponivel em: https://g1.globo. com/politica/noticia/2019/07/10/bolsonaro-diz-que-vai-indicar-ministro-terrivelmente-evangelico-para-o-stf.ghtml. Acesso em: 20 maio 2019.

5 Ministros de Bolsonaro almoçam com bancada evangélica para prestar contas do governo. Esquerda Diário. Edição do Dia. 13 set. 2019. Disponivel em: http://www.esquerdadiario.com.br/Ministros-de-Bolsonaro-almocam-com-bancada-evangelica-para-prestar-contas-do-governo. Acesso em: 12 out. 2019.

6 Infladas por Bolsonaro, bancadas temáticas perdem força no Congresso. Jornal do Brasil. 14 set. 2019. Disponivel em: https://www.jb. com.br/pais/2019/09/1016566-infladas-por-bolsonaro--bancadas-tematicas-perdem-forca-no-congresso.html. Acesso em: 15 out. 2019. 7 Comissão do Senado debate proposta para restringir aborto nesta quarta. El País. Brasil. 8 maio 2019. Disponível em: https://brasil. elpais.com/brasil/2019/05/07/politica/1557249816_970062.html. Acesso em: 10 out. 2019.
} 
gabinete do deputado federal João Campos (PRB), autor do denominado projeto da "cura gay", que "Dispõe sobre o direito à modificação da orientação sexual em atenção a Dignidade Humana", ${ }^{8}$ e está alinhada à bancada evangélica, que denomina o projeto de Magno Malta como "PEC da Vida", o qual versa, no entanto, sobre proibir ou dificultar o acesso ao aborto seguro e legal.

Discursos sobre a sexualidade são resultantes de uma grande rede de jogos pelo poder, que estimula os corpos, intensifica os prazeres, interpela e incita aos discursos, tanto quanto podem precarizar a vida e conduzir a uma potencialização da violência, a uma vulnerabilidade física de certo grupo de pessoas (BUTLER, 2017). No que concerne à trama entre política e religião, a sexualidade tem sido emparedada pelos discursos da chamada "familia tradicional" no Congresso brasileiro, ancorados pela Teologia da Prosperidade ${ }^{9}$ e por uma ritualística essencialmente dualista, assentada em pregações que evocam signos complexos e escorregadios como os da "libertação", "cura" e "exorcismo".

A título de argumento, o Art. $1 .^{\circ}$ do denominado "projeto da cura gay" está desse modo escrito:

Fica facultado ao profissional de saúde mental, atender e aplicar terapias e tratamentos científicos ao paciente diagnosticado com os transtornos psicológicos da orientação sexual egodistônica, transtorno da maturação sexual, transtorno do relacionamento sexual e transtorno do desenvolvimento sexual, visando auxiliar a mudança da orientação sexual, deixando o paciente de ser homossexual para ser heterossexual, desde que corresponda ao seu desejo (CÂMARA FEDERAL, 2019) ${ }^{10}$.

Sabemos que esses discursos formam conhecimentos, fortalecem controles e resistências, movimentam desejos, os quais se encadeiam em uma teia complexa de estratégias de saber e poder. A proposição binária, fortemente atrelada a uma "gramática pentecostal" (NOVAES, 2003) - bem/mal; Deus/Diabo; heterossexual/ homossexual; cura/transtorno; "menino veste azul/menina veste rosa"11 - tem sido útil para os propósitos político-religiosos, cuja agenda afirma visões e valores morais reativos. Todavia, sua operação não é simples ou esquemática, pois nenhum desses termos - "transtornos psicológicos da orientação sexual egodistônica", "mudança da orientação sexual", "desejo" -, existem fora de uma organização e interpretação políticas.

Trata-se de termos interessados, organizados como "armas de guerra" (BENTO, 2017). Eles manipulam contra as sexualidades dissidentes, um tipo de essencialismo que é estratégico para fazer avançar pautas dogmáticas e reacionárias; constituem enquadramentos discursivos que funcionam como "quadros de guerra" (BUTLER, 2017. p. 17) e regulam os modos como em sociedade se responde afetiva e moralmente, por exemplo, às violências ocorridas com a população LGBT. Quem chora a morte de gays, lésbicas, transexuais e travestis no Brasil?

Questionar a natureza da linguagem interessada em "maximizar a precariedade para alguns e minimizar a precariedade para outros" (BUTLER, 2017, p. 15) -, o fechamento narrativo, a interpretação, o contexto, as condições de produção e recepção dos discursos, a representação - uma prática metafórica e mimética -, torna-se, pois, fundamental na luta por equidade de direitos, haja vista que não sendo apenas um enunciado, um conjunto de palavras, os discursos atuam (i) no sentido de determinar quem é humano e, por conseguinte, qualificado para direitos humanos; (ii) sancionam formas de ódio e abjeção de cunho cultural e religioso.

Roland Barthes (2004), Jacques Derrida (2001),

8 Damares Alves, a militante antiaborto alçada a pastora de Bolsonaro na Esplanada. El País. Brasil. Brasília. 7 dez. 2018. Disponível em: https://brasil.elpais.com/brasil/2018/12/06/politica/1544130330_946126.html. Acesso em: 10 out. 2019.

9 A Teologia da Prosperidade (TP) está relacionada a crenças que envolvem cura espiritual, prosperidade financeira e poder sobrenatural da fé. No contexto da Teologia da Prosperidade, o discurso da igreja sobre a prosperidade e a vida em abundância, é atravessado por outras prerrogativas, a saber, a fidelidade e o sacrifício. Sobre esse tema, sugere-se conferir o estudo de Maria Iris Abreu Santos (2015). 10 PROJETO DE LEI 4931/2016. Dispõe sobre o direito à modificação da orientação sexual em atenção a Dignidade Humana. Câmara Federal. Disponivel em: https://www.camara.leg.br/proposicoesWeb/fichadetramitacao?idProposicao=2081600. Acesso em: 10 out. 2019. 11 Em vídeo gravado após assumir cargo em alto escalão do governo de Jair Messias Bolsonaro, a ministra Damares Alves (Mulher, Família e Direitos Humanos), que é advogada e pastora evangélica, afirmou: "Atenção, atenção! É uma nova era no Brasil, meninos vestem azul e meninas vestem rosa". Em vídeo, Damares diz que 'nova era' começou: 'meninos vestem azul e meninas vestem rosa'. G1. Política. Brasilia. 03/01/2019. Disponivel em: https://g1.globo.com/politica/noticia/2019/01/03/em-video-damares-alves-diz-que-nova-era-comecou-no-brasil-meninos-vestem-azul-e-meninas-vestem-rosa.ghtml. Acesso em: 20 ago. 2019. 
Judith Butler (2017), Michel Foucault (2012) são teóricos que, guardadas as devidas diferenças, levaram longe a análise dos textos procurando libertar a escrita, a oralidade, a interpretação, a tradução, tanto da autoridade do logos, que exigia o papel de mera expressão de uma voz original, com um sentido autêntico a ser encontrado, quanto do estigma da orfandade ou da bastardia.

Não há, pois, um Pai ou uma Bíblia da linguagem para o qual se deva retornar, não interessa "fazer confundir fraudulentamente a origem do fato e a sua manifestação mais longínqua", até porque, isso é "próprio a todos os regimes autoritários; é o que se poderia chamar de escrita policial: conhece-se, por exemplo, o conteúdo eternamente repressivo da palavra 'Ordem'" (BARTHES, 2004, p. 23). Ora, o gesto de inscrição que constitui a escrita, o escritor e uma proliferação de sentidos devem ser reunidos por cada leitor-tradutor-intérprete, assim, todo interprete é um interventor que não escapa às questões institucionais mais amplas da regulação social da cultura, não havendo, portanto, que se falar em significado fixo ou origem.

Na trama do discurso, o que ocorre são jogos de linguagem e lutas pelo poder, remetendo a cadeia de significante a uma significação sempre diferida, o que contraria a dominação dos estereótipos, a tirania das normas e o discurso da Ordem.

Três apontamentos nos servirão de guia, no presente artigo, ao problematizar discursos político-religiosos, a saber: (i) as palavras cujos enunciados não são meramente descritivos, mas também prescritivos, estão sendo utilizadas para o controle do corpo dos sujeitos; (ii) os sujeitos cujos corpos/comportamentos não se encaixam no mundo biunivoco, constantemente são convocadas a dar explicações acerca de sua existência, ou seja, são interpelados a "sairem do armário"; violentamente, são convocados à Confissão; (iii) os sujeitos que se desviam da heteronorma tendem a ter vida precária com seus direitos civis reduzidos, sendo tratados como abjetos, ainda que as expressões utilizadas nos discursos político-religiosos sejam encapadas com eufemismos e suposta neutralidade.

\section{Do discurso restritivo e sua encenação da verdade}

Há muito que a sexualidade não é mais um assunto privado, apenas. Desde os anos 1960, transformações sociais profundas construiram formas de relacionamento diversas daquelas instituidas como patriarcais, monoparentais, cisgêneras e/ou privadas. Novas tecnologias surgiram, o investimento do Estado se fez cada vez mais presente no corpo das pessoas, bem como o acesso à rede mundial de computadores, apontam-nos que existem outras formas de gerar, namorar, crescer, amar, fazer amor.

Desde a redemocratização, na década de 1980 , passando pelo ressoar no Brasil dos debates feministas e gays ocorridos nos Estados Unidos da América e em alguns paises da Europa como França e Espanha, com o advento da AIDS, um crescente interesse sobre estudos em homocultura tem lugar. Desprendendo-se esses estudos das relações entre saúde e doença, a década de 1990 assistiu a uma diversificação de pesquisas que passaram a ter objetivos voltados para a compreensão dos processos de sociabilidades concernentes às vivências e experiências políticas desses sujeitos.

No que se refere às homossexualidades, figuras de destaque mundial, tais como esportistas, religiosos, políticos, têm assumido seus afetos. Para citar apenas alguns exemplos, recordemos: Diego Hypólito (atleta), Tom Bosworth (velocista britânico), Liz Camouche (lutadora norte-americana do UFC), Peter Mandelson (ex secretário do governo Britânico), Bertrand Delanoe (ex-prefeito de Paris), Annise Danette Parker (prefeita de Houston, EUA).

As homossexualidades pulsam na sociedade brasileira tanto quanto em qualquer outra, mesmo punida, cerceada, vigiada. Basta olharmos os noticiários, a mídia, as telenovelas, os programas de auditório e entrevistas, os debates para os cargos públicos, para percebermos que as homossexualidades são um tema colocado.

Casais homoafetivos advogam o direito à adoção de crianças, dentre outras pautas, colocando a homossexualidade na ordem do 
dia - e fora do armário? A homoafetividade se apresenta quase que cotidianamente em programas de televisão, logo, não é tema de cunho restrito. Não obstante as representações se aproximarem da heteronormatividade, "justo aquela que é, em boa medida, responsável pela criação dos preconceitos e a manutenção da falta de respeito à diversidade sexual e de gênero" (COLLING, 2013, p. 107).

Leandro Colling, como resultado de pesquisa realizada de 2007 a 2011 pelo Grupo de Pesquisa Cultura e Sociedade (CUS) da Universidade Federal da Bahia (UFBA), sobre a performatividade de gênero das personagens não heterossexuais nas telenovelas da Rede Globo, exibidas de 1998 a 2008, considera que: i) há apagamento de diferenças entre heterossexuais e não heterossexuais; ii) a performatividade de gênero se coaduna com aquela esperada para o sexo biológico; iii) é frequente a adoção de um discurso de normalidade e naturalidade da homossexualidade; iv) persiste a submissão do gay afetado pelo gay macho ou um casal; e v) gays não têm vida sexual ativa nas novelas. Assim, sujeitos cujas sexualidades são dissidentes são aceitos nas representações televisas, desde que incorporados a um modelo heteronormativo.

Infelizmente, na contramão da efervescência das sexualidades dissidentes em nossa sociedade, mesmo com os avanços tecnocientíficos, o fortalecimento das discussões em torno dos Estudos queer (LOURO, 2001) e da dignidade humana, ainda se insiste em um discurso único, essencialista e binário acerca da sexualidade, materializando uma não identidade, uma identidade que não importa e deve ser excluida por meio da abjeção.

A heterossexualidade compulsória, ${ }^{12}$ ou seja, a exigência de que todos os sujeitos sejamos heterossexuais, sendo essa a única forma considerada normal de vivência da sexualidade, assenta-se na crença em uma verdade, a saber, que há um sexo pré-discurso a atuar como ponto de referência estável sobre o qual, ou em relação ao qual, se realizaria a construção da sexualidade, desejo e gênero. Essa "construção" acredita-se (paradoxalmente) natural - e verdadeira -, uma vez que espelharia uma realidade biológica.

Para além de conquistas, o discurso heterohegemônico ainda obstina-se a restringir o campo da significação, remetendo-nos ao "homem branco, heterossexual, de classe média urbana e cristão" (LOURO, 2001, p. 15), signo e referência impar que não precisa (supostamente) mais ser nomeada ou explicada porque tem "efeito de verdade" (FOUCAULT, 1988), adquirido às custas de coerções múltiplas.

Todavia, o "signo heterossexual" é um símbolo no sentido que utilizou Charles Sanders Peirce (SANTAELLA, 1992), sinal representante de uma realidade em que a relação entre significantes e o significado não é lógica e necessária, mas convencional. Ou seja, é deste jeito, mas poderia ser de outro. Trata-se de algo que aponta para a arbitrariedade das coisas, para a centralidade da cultura e seus jogos pela manutenção do poder. Acompanhando Jacques Derrida (2001), o que se apreende é que não há significado por trás do significante, não há um significado na origem, até porque esta não é preexistente ao sentido. E que o sentido é efeito constituido por uma cadeia de significantes em um processo de diferimentos, logo, o reforço heteronormativo é um "efeito de verdade" - nunca "a" verdade" -, e segue a "regimes de verdade" presentes em qualquer sociedade.

Certos discursos são aceitos e funcionam como verdadeiros. A sociedade os sanciona e os convalida, determina as instituições, os mecanismos e as instâncias em que dado enunciado terá valor de verdade. Distinguindo os aceitos daqueles que terão a pecha da falsidade, estabelece técnicas e procedimentos que serão valorizados para a obtenção da verdade, legitima os estatutos daqueles que têm a função de dizer como funciona o verdadeiro. 


\section{Do discurso religioso-político}

O pesquisador Luiz Mott (1999) lembra-nos que gays viveram "tempos sombrios" sob o pontificado de João Paulo II, pois, mais do que outro qualquer Papa, foi quem estigmatizou de forma cruel o amor entre pessoas do mesmo sexo, ao oficializar a intolerância do "inquisidor-Mor" Ratzinger - que se tornaria o Papa Bento XVI -, declarando: "a homossexualidade é intrinsecamente má" (MOTT, 1999, 37).

O alemão Joseph Ratzinger tornou-se Papa em abril de 2005 e, durante o seu pontificado, reforçou a guinada conservadora da Igreja Católica, iniciada com o cardeal polonês Karol Wojtyla, o papa João Paulo II. Lider da Congregação para a Doutrina da Fé, órgão da Inquisição, Bento XVI não se furtou a perseguir setores mais vanguardistas da igreja e promover guinada antiprogressista ao retomar dogmas católicos antigos. Em sua "Carta aos bispos da Igreja Católica sobre a colaboração de homens e mulheres na lgreja e no mundo", afirmou:

Essa teoria da pessoa humana, concebida para promover perspectivas igualitárias para as mulheres, libertando-as do determinismo biológico, tem, na realidade, inspirado ideologias que, por exemplo, colocam em questão a família, em sua estrutura natural de um casal formado pelo pai e pela mãe, tornando a homossexualidade e a heterossexualidade virtualmente equivalentes em um novo modelo de sexualidade polimorfa (VATICANO, 2004). ${ }^{13}$

A Igreja de Ratzinger, atingida por denúncias gravissimas e constrangedoras tais como padres pedófilos e fortunas erguidas ilegalmente pelo Vaticano, é a mesma que não convalidou "a Carta dos Direitos Humanos da ONU, sob o pretexto de que não faz nenhuma referência a Deus, e retirou seu apoio ao Unicef, agência das Nações Unidas, porque aconselha o uso de preservativos para combater a Aids e fazer o planejamento familiar".14
O atual pontífice, Papa Francisco, tem demonstrado maior flexão em relação às causas homoafetivas, o que, no entanto, não impediu que a Conferência Nacional dos Bispos (CNBB) enviasse o advogado Hugo José Sarubbi Cysneiros de Oliveira ${ }^{15}$ para representá-la no Supremo Tribunal Federal (STF) no momento de análise de constitucionalidade de ampliação de direitos aos homossexuais, a saber, aqueles relacionados à união homoafetiva.

Em sustentação oral perante a tribuna do STF, na qualidade de amici curiae (amigo da Corte), afirmou Cysneiros que "afeto não pode ser parâmetro para constituição de união homoafetiva estável". Para o bacharel, "a pluralidade tem limites", não sendo necessário deslocar a questão para o direito natural, pois, "nós temos aqui uma discussão juridica, dogmática, positivada, temos uma Carta que disciplina o tema, que estabelece, numerus clausus, quais são as hipóteses de família e de união estável".16

Nenhuma surpresa que o Vaticano entenda que os direitos de gays, lésbicas, bissexuais, transexuais e travestis, sejam "anti-humanos" (BUTLER, 2002, p. 134), uma vez que já afirmou: "A humanidade aqui é descrita como articulada, desde a sua primeira origem, na relação do masculino e do feminino. É esta humanidade sexuada que é explicitamente declarada 'imagem de Deus'". ${ }^{17}$

A visão simplista da humanidade segundo a qual, "homossexualidade é pecado", pautada em discurso bíblico, "Adão e Eva", na relação pênis/ vagina, na familia heterossexual, patrilinearmente definida, é sustentáculo de agressões diversas que envolvem os sujeitos que ali não se enquadram. Dores psiquicas, emocionais, dores no corpo e na alma, problemas com a familia, expulsão de casa, diminuição de direitos civis, dificuldades

\footnotetext{
13 CARTA aos bispos da Igreja Católica sobre a colaboração do homem e da mulher na Igreja e no mundo. Vaticano. Roma, Sede da Congregação para a Doutrina da Fé, 31 de maio de 2004. Festa da Visitação de Nossa Senhora. Disponivel em: http://www.vatican.va/ roman_curia/congregations/cfaith/documents/rc_con_cfaith_doc_20040731_collaboration_po.html. Acesso em: 20 ago. 2019.

14 Teólogo diz que Bento XVI infantiliza os fiéis, é complacente com os pedófilos e fechou as portas para as outras religiões. ISTO É. o2 jun. 2010, $n^{\circ}$ 2116. Disponivel em: https://istoe.com.br/76149_O+PAPA+DEVERIA+RENUNCIAR+/. Acesso em: 20 ago. 2019.

15 Cysneiros é assessor juridico da Nunciatura Apostólica do Brasil, da Conferência Nacional dos Bispos do Brasil (CNBB), da Conferência dos Religiosos do Brasil - CRB, da Associação Nacional de Educação Católica do Brasil - ANEC. SCA Advogados. Disponivel em: https://www.scaadv.com.br/equipe/hugo. Acesso em: 20 ago. 2019.

${ }_{16}$ Afeto não pode ser parâmetro para união homoafetiva, diz CNBB. STF. Brasília. 7 abr. 2020. Disponivel em: http://www.stf.jus.br/por$\mathrm{tal} / \mathrm{cms} /$ verNoticiaDetalhe.asp?idConteudo=178775. Acesso em: 20 ago. 2019. Acesso em 20 ago. 2019.

17 CARTA aos bispos da Igreja Católica sobre a colaboração do homem e da mulher na Igreja e no mundo. Vaticano. Roma, Sede da Congregação para a Doutrina da Fé. 31 de maio de 2004. Festa da Visitação de Nossa Senhora. Disponivel em: http://wwww.vatican.va/ roman_curia/congregations/cfaith/documents/rc_con_cfaith_doc_20040731_collaboration_po.html. Acesso em: 20 ago. 2019.
} 
em encontrar e se fortalecer no trabalho, ter amizade ou ensino de qualidade e desenvolver vida qualificada, são alguns dos problemas resultantes da visão binária sustentada, muitas vezes, em nome da religião e da política.

A Confederação Nacional dos Bispos do Brasil (CNBB) que, paradoxalmente afirma se comprometer com o combate a todo tipo de discriminação, ${ }^{18}$ emitiu nota em junho de 2015 alertando para tentativas de se incorporar a "ideologia de gênero" nos Planos Estaduais e Municipais de Educação no Brasil. Segundo ela, o combate à discriminação contra gays não deve ocorrer na escola, haja vista que o "Plano Nacional de Educação" fora aprovado sem os termos "gênero" e "homoafetividade".

A nota emitida pela CNBB é iniciada com uma epígrafe, qual seja "Homem e mulher, Ele os criou", retirada do Gênesis, primeiro livro do texto biblico.19 Esse mesmo discurso, corriqueiramente utilizado por igrejas neopentecostais que se posicionam contra direitos homoafetivos, vem acompanhado de outros, a saber, que a identidade sexual não é uma construção eminentemente cultural, com a consequente escolha pessoal; a ideologia de gênero desconstrói o conceito de família, que tem seu fundamento na união estável entre homem e mulher.

Ora, retomemos por um instante, o discurso da Cruz, delatado por Michel Foucault (2010) em Os anormais sob a marca dos dispositivos de poder. A nota assinada pela CNBB faz parte de um dispositivo, atrelado e manietado por um jogo de poder, está ligada a uma configuração de saber, resultado e resultante de estratégias de relações de força promotoras de modos de conhecimento. A nota da CNBB expressou o desejo de regular os corpos, o que faz parte da tecnologia cristã de governo dos indivíduos, logo, busca controlar os efeitos dessa carne convulsiva, desse corpo de movimento, de agitação e de prazer, e isso por diferentes meios, tanto nos estabelecimentos de ensino como nos seminários, nos internatos, nas escolas, nos colégios (FOUCAULT, 2010).

A nota politico-religiosa se posiciona frente aos avanços e interesses feministas e de sujeitos cujas sexualidades são dissonantes. Pretende fazer calar e silenciar a possibilidade de se discutir as questões de gênero nas escolas. Trata-se de um movimento que pretende lançar os "anormais" para dentro do armário, o qual, contudo, num duplo gesto, busca conter os desejos e os corpos, apagando qualquer possibilidade de incêndio discursivo, mas deixa entrever os interesses silenciados que gritam de seus lugares esquadrinhados e supostamente límpidos.

O policiamento dos corpos dissidentes nos colégios, nas escolas, nas praças, no texto da CNBB se dá por meio da organização de "lugares", visiveis e invisiveis, materiais e simbólicos: a disposição das latrinas, as cores das paredes, os banheiros apartados, a disposição dos materiais e dos corpos, pois, "Homem e mulher, Ele os criou". Essa separação, esse desejo de silenciamento, paradoxalmente, ao invés de cabalmente eliminar o assunto, fala dele, grita, expõe, nomeando os "perigosos" corpxs de prazer desgarrados.

Tomem-se as declarações do bispo de Guarulhos, SP, Dom Luiz Gonzaga Bergonzini, falecido em junho de 2012, como paradigmáticas da ação da Igreja. Ele acreditava que o Brasil é uma sociedade que vive em pecado, por ter equiparado, por meio de julgamento no Superior Tribunal Federal (STF), o "casamento homossexual com o matrimônio fundado no Sacramento" e por promover o "homossexualismo entre as crianças em idade escolar com o famigerado kit anti-homofobia".20

Afirmava o bispo que o Partido dos Trabalhadores - PT -, estaria colocando em prática estratégias para desenvolver o Programa Nacional de Direitos Humanos PNDH-3, que postularia

18 "A CNBB reafirma o compromisso da Igreja em se somar aos que combatem todo tipo de discriminação a fim de que tenhamos uma sociedade sempre mais fraterna e solidária". CNBB divulga nota sobre inclusão da ideologia de gênero nos Planos de Educação. Palavras da CNBB. Brasilia. 24 jun. 2015. Disponivel em: https://jovensconectados.org.br/cnbb-divulga-nota-sobre-inclusao-da-ideologia-de-genero-nos-planos-de-educacao.html. Acesso em 20 ago. 2019.

19 CNBB divulga nota sobre inclusão da ideologia de gênero nos Planos de Educação. Palavras da CNBB. Brasilia. 24 jun. 2015. Disponivel em: https://jovensconectados.org.br/cnbb-divulga-nota-sobre-inclusao-da-ideologia-de-genero-nos-planos-de-educacao.html. Acesso em 20 ago. 2019.

20 VENHAM conosco lutar pela vida humana. Dom Luís Bergonzini. Guarulhos, São Paulo. 8 de abril de 2011. Disponivel em: http://www. domluizbergonzini.com.br/2011/04/venham-conosco-lutar-pela-vida-humana.html. Acesso em 24 maio 2019 
o aborto, o ensino do "homossexualismo" e o banimento de símbolos religiosos de espaços públicos. Queixava-se:

Os ministros indicados pela presidente Dilma Rousseff são historicamente favoráveis ao aborto, ao casamento homossexual e outros pontos que contrariam o Evangelho. A presidente retirou o crucifixo da sala da presidência. As missas e as pregações evangélicas, que estão nas televisões públicas há mais de 30 anos, serão retiradas. O roteiro de guerra contra os cristãos, como foi anunciado pelo presidente Lula no PNDH3, continua (Dom Luis Bergonzini, 2011). ${ }^{21}$

Se no ocidente novecentista a lgreja lançou-se a uma cruzada contra a masturbação - consequência e instrumental da formação da sociedade capitalista, produtiva/coercitiva -, cuja necessidade era a de se adaptar os corpos à noção de família, produção e patriarcado, a nota dos religiosos e a guerra de Bergonzini levam a homossexualidade ao campo da desrazão, da animalidade porque, segundo eles, tenta desconstruir os ideais em que se assentam a familia.

\section{Do discurso político-religioso}

Programas do governo federal como o "Brasil Sem Homofobia" de 2004, buscaram combater a violência e promover a cidadania de gays, lésbicas, travestis e transexuais, focando principalmente a igualdade no acesso à Educação. Todavia, políticas públicas demonstraram pouco fôlego, caminharam a passos lentos e encontraram ferrenha oposição por meio de parlamentares, especialmente ligados a religiões pentecostais e neopentecostais.

De 2004 para cá, com o decréscimo nos investimentos, uma verdadeira crise nas verbas destinadas ao combate à violência a Lésbicas, Gays, Bissexuais e Travestis (LGBT) tem tido lugar. O governo do presidente Michel Temer reduziu a zero, em 2017, os repasses federais para programas especificos de defesa da comunidade LGBT; levou a termo uma forte política econômica privatista e neoliberal, com um eixo ultraconservador, que flerta com o fascismo ${ }^{22}$. Extinguiu o Ministério das Mulheres, Igualdade Racial, Juventude e Direitos Humanos; convidou para compor seus ministérios, inicialmente, apenas homens, de idade alta e gordas contas bancárias.

A estrutura do Ministério dos Direitos Humanos, criado por Luís Inácio Lula da Silva, em 2003, foi picotada e alguns ministérios, como o da Justiça, retrocederam à roupagem similar a dos idos da década de 1990. Os setores fundamentalistas cristãos ganharam destaque, sustentando o discurso contrário ao que denominaram como "ideologia de gênero", especialmente contemplado no PL 867/2015, proposição que se referenda em anteprojeto de lei elaborado pelo movimento "Escola sem Partido", o qual assina, dentre outros argumentos que justificariam o referido Projeto de Lei:

É fato notório que professores e autores de livros didáticos vêm-se utilizando de suas aulas e de suas obras para tentar obter a adesão dos estudantes a determinadas correntes politicas e ideológicas; e para fazer com que eles adotem padrões de julgamento e de conduta moral especialmente moral sexual - incompativeis com os que thes são ensinados por seus pais ou responsáveis (CÂMARA DOS DEPUTADOS, 2015). ${ }^{23}$

Mais de 30 pastores cuja pauta é antiLGBT, alinhados a condutas reacionárias foram convidados a compor a agenda reativa, demonstrando não se interessar por direitos civis a LGBT, a não ser para lhes reduzir o espaço e aumentar o rechaço. O governo de Michel Temer prestou um desserviço a essa população.

Em artigo intitulado "Uma ponte para o armário",24 Cleyton Feitosa, doutorando em Ciência Política

\footnotetext{
21 Se o PNDH-3 banir Jesus Cristo o que será do Brasil? Dom Luís Bergonzini. Guarulhos, São Paulo. 12 jun. 2011. Disponivel em: http:// www.domluizbergonzini.com.br/2011/06/se-o-pndh-3-banir-jesus-cristo-o-que.html. Acesso em 24 maio 2019.

22 Sobre o flerte com o fascismo, vale conferir pesquisa de Marilia Martins Mendes (2018), a qual analisou discursos de lideranças politicas de direita no Brasil, concluindo que gestam o fascismo e impõem limites à democracia formal.

23 PROJETO DE LEI 867/2015. Inclui, entre as diretrizes e bases da educação nacional, o "Programa Escola sem Partido". Câmara dos Deputados. 23 Mar. 2015. Disponivel em: https://www.camara.leg.br/proposicoesWeb/fichadetramitacao?idProposicao=1050668. Acesso em: 20 maio 2019.

24 O título de seu texto "Uma Ponte para o Armário" é um trocadilho com o lema governista "Ponte para o futuro" e a expressão "sair do armário", momento em que os sujeitos LGBT, supostamente, conseguem expressar seus desejos sem precisar viver às escondidas. Construção da cidadania LGBT passa pelo resgate da democracia. Congresso Em Foco. 21 jun. 2017. Disponivel em: http://congressoemfoco. uol.com.br/opiniao/construcao-da-cidadania-lgbt-passa-pelo-resgate-da-democracia/. Acesso em: 20 maio 2019.
} 
pela Universidade de Brasilia (UnB), discute o desmonte das políticas LGBT no governo de Michel Temer. Estariamos segundo seus argumentos, vivendo sob as marcas da invisibilidade, humilhação, constrangimento e negação de direitos LGBT, cujas lutas estão enfraquecidas.

Os investimentos federais em políticas voltadas para o público LGBT, foram caindo de R\$ 3 milhões em 2008 para R\$ 519 mil em 2016. Os programas foram encolhendo e sendo desativados. Existentes durante o governo de Lula Inácio Lula da Silva, os programas "Fomento a Projetos de Combate à Homofobia", "Apoio a Serviços de Prevenção e Combate à Homofobia" e "Banco de Dados sobre Cidadania Homossexual e Combate à Homofobia" deram espaço, no governo Dilma Rousseff, sua sucessora, a partir de 2013, para ações da "Promoção e Defesa dos Direitos de Lésbicas, Gays, Bissexuais, Travestis e Transexuais", cujos recursos diminuidos foram centralizados. Eleita presidenta, Rousseff promoveu políticas LGBT e buscou atender as demandas dessa população, embora tenha vetado o programa "Escola sem Homofobia" e flertado com os cristãos, vide a "Carta aos Cristãos".25

No Congresso Nacional tramitam ao menos cinco projetos de lei que têm como objetivo coibir o ensino, nas escolas, daquilo que denominam de "ideologia de gênero" e outras formas de "ameaças à familia". Em assembleias legislativas de pelo menos nove estados da federação e em outros 13 municípios, incluindo capitais como São Paulo, Rio de Janeiro e Curitiba, também há projetos deste tipo. Na Câmara Federal tramita Projeto de Lei 3235/2015, ${ }^{26}$ de autoria do Deputado Marco Antônio Feliciano do Partido Social Cristão (PSC), que acrescenta artigo ao Estatuto da Criança e do Adolescente, segundo o qual ficaria proibido:

Art. 234-A Veicular a autoridade competente, em atos normativos oficiais, em diretrizes, planos e programas governamentais, termos e expressões como 'orientação sexual', 'iden- tidade de gênero', 'discriminação de gênero', 'questões de gênero' e assemelhados, bem como autorizar a publicação dessas expressões em documentos e materiais didático-pedagógicos, com o intuito de disseminar, fomentar. induzir ou incutir a ideologia de gênero. Pena - detenção, de seis meses a dois anos, e multa (DEPUTADO MARCO FELICIANO, 2015).

No texto assinado pelo deputado, pode-se ler que "a ideologia de gênero adquiriu sua configuração semântica atual no início dos anos 1990, com a obra da professora Judith Butler" (FELICIANO, 2015). A chamada "ideologia de gênero" seria uma deliberada "estratégia para suplantar progressivamente a clivagem biológica dos sexos, para substituí-la pela de gêneros, enquanto constructos culturais de caráter difusamente identitário" (FELICIANO, 2015). Dai seu objetivo de incluir no Estatuto da Criança e do Adolescente um dispositivo que criminaliza "todo intento de disseminar, fomentar, induzir ou incutir a deletéria ideologia de gênero" (FELICIANO, 2015) e seus sinônimos - "orientação sexual", "identidade de gênero", "discriminação de gênero", "questões de gênero" - em documentos e materiais didático pedagógicos, bem como em atos normativos oficiais, em diretrizes, planos e programas governamentais.

O cenário denuncia um embate de forças e uma sanha totalitária a destruir redes, articulações políticas, reprimindo, anulando, agredindo, silenciando vozes contrárias ao instituído como normal. Trata-se do discurso sendo usado como armas de guerra porque a ação do deputado não se desvia de uma postura fascista. Busca o apagamento de grupos e organizações, incide sobre a história tentando reescrevê-la, produzindo um sistema único de interpretações e construção do que seja "a" verdade.

Em debate na TV Câmara, o Deputado Pastor Eurico $^{27}$ foi enfático:

Gente, todos nós quando falávamos algum tempo atrás em gênero se subentendia: gê-

\footnotetext{
25 Carta aberta ao Povo de Deus - Dilma Rousseff. Coluna do blog da Lúcia. 15 de outubro de 2010. Disponível em: http://colunadoblogdalucia.blogspot.com/2010/10/carta-aberta-ao-povo-de-deus-dilma.html. Acesso em: 20 maio 2019.

26 PROJETO DE LEI N 3235. DE 2015. Acrescenta o art. 234-A à Lei n 8.069, de 13 de julho de 1990, que "Dispõe sobre o Estatuto da Criança e do Adolescente e dá outras providências". Câmara dos Deputados. Disponivel em: http://www.camara.gov.br/proposicoesWeb/prop_mostrarintegra?codteor=1397228. Acesso em: 20 maio 2019.

27 O Deputado Pastor Eurico assina com o nome civil de Francisco Eurico da Silva. Representa o Partido Humanista da Solidariedade (PHS/PE).
} 
nero masculino, feminino, essa é posição da palavra gênero que era costumeira entre nós. Nos últimos anos a palavra gênero foi levada para uma outra linha, que é essa linha que nos combatemos nas escolas que tem projetos aqui miseráveis que afrontam os direitos das crianças, dos pais sobre os filhos e do ensinamento do que é o masculino e o feminino. Esse movimento encabeçado pelos ativistas homossexuais que querem introduzir gênero como sendo hoje na linguagem popular nua e crua: a desconstrução daquilo que é a criação tal qual Deus criou homem, mulher, macho e fêmea. A ideologia de gênero defende que criança não pode ser embutida na cabeça dela, que ela nasceu macho/homem, fêmea/mulher ela nasceu um ser e ela vai desenvolver sua sexualidade. Isso é um absurdo! Nós não podemos aceitar uma coisa dessas! (PASTOR EURICO, 2019). ${ }^{28}$

O "absurdo" ao qual se refere o deputado, tem a ver com o que o pensamento reativo brasileiro convencionou chamar de "ideologia de gênero". Na verdade, a sustentação do pastor é uma manobra discursiva que ataca a possibilidade de se democratizar as formas de ser e de existir, e reitera ser a homossexualidade, de antemão, um "problema" contra o qual se deve lutar.

Segundo o deputado pastor, há projetos "miseráveis que afrontam os direitos das crianças, dos pais sobre os filhos e do ensinamento do que é o masculino e o feminino", e prossegue acusando os chamados "ativistas homossexuais" de introduzir gênero como "a desconstrução daquilo que é a criação tal qual Deus criou" (PASTOR EURICO). Ou seja, seu discurso acolhe o tratamento dispensado às homossexualidades como "inversão", "desvio", "perversão", isto é, algo que iria de encontro à ideologia da "normalidade".

\section{Do discurso como bomba, exército, drone}

Não é nenhum acaso, portanto, o que ocorre no Brasil, pais internacionalmente conhecido como cordial e ordeiro (OLIVEIRA; MARTINS 2009), mas que, paradoxalmente, convive com dados alarmantes e controversos que apontam para a violência com a qual se trata a diferença. Os discursos se desdobram em ações, e nunca se apartam. São discursos-bombas, discursos-exércitos, discursosdrones, discursos-bloqueio, colocados nas ruas para vigiar, punir, matar os desviantes das normas heterossexuais, exemplarmente.

Em 2007, após sair de um salão de beleza, a transexual Renata Peron, de 38 anos, foi cercada e atacada por um grupo de nove pessoas. Ela perdeu um dos rins, ficou internada por 15 dias e tenta se recuperar de trauma psicológico. Em dezembro de 2012, dois homens espancaram o estudante de Direito da Universidade de São Paulo (USP), André Baliera, de 27 anos. Ele voltava a pé para casa quando foi agredido. Em agosto de 2014, em um restaurante japonês na Rua Augusta, Jonathan Favari, de 25 anos, e o namorado Gabriel Cruz, de 24, foram agredidos pelo garçom após o casal dar um "selinho".

A cada sete dias, a Polícia Civil do estado de São Paulo registra ao menos uma ocorrência de violência física ou verbal contra homossexuais na capital. Dos 133 boletins de ocorrência registrados até outubro de 2015, 42 estavam relacionados a vítimas LGBT. Entre 2010 e 2014 . foram contabilizados 880 crimes, sendo 218 deles, ou seja, $24,7 \%$, por intolerância. Os delitos mais cometidos são injúria e lesão corporal por discriminação de orientação sexual e identidade de gênero: 50,4\% e 19,7\%, respectivamente.

Em 2017, 445 lésbicas, gays, bissexuais, travestis e transexuais (LGBT) foram mortos em crimes motivados por homofobia. ${ }^{29}$ Se por um lado, cresceu a parcela de brasileiros que concordam que a homossexualidade deve ser aceita pela sociedade (de 67\% em 2013 para 74\% em 2017), por outro lado, o número de homicídios de pessoas cujas sexualidades são desviantes da norma $^{30}$, registrou crescimento de 30\% em 2017.

No Brasil, a expectativa média de vida de uma travesti e de uma transexual é de apenas 36 anos contra a média do restante da população

\footnotetext{
28 Pastor Eurico debate Escola Sem Partido. Câmara Debate. Disponivel em: https://www.youtube.com/watch?v=alcG6Ew26Uw. Acesso em 12 ago. 2019.

29 Levantamento aponta recorde de mortes por homofobia no Brasil em 2017. Agência Brasil. 18 jan. 2018. Disponível em: http:// agenciabrasil.ebc.com.br/direitos-humanos/noticia/2018-01/levantamento-aponta-recorde-de-mortes-por-homofobia-no-brasil-em. Acesso em: 20 maio 2019

30 Utilizamos termos "sexualidades dissidentes", "sexualidades não heteronormativas", "sexualidades sinuosas", "sexualidades queer", como intercambiáveis, apontando para uma fuga em relação à heteronormatividade compulsória.
} 
que é de 73 anos. De cada 10 assassinatos de transexuais que ocorre no mundo, 4 se referem ao Brasil. Somos o país mais violento no mundo para transexuais. De 2.609 homicidios reportados de pessoas trans e de gênero diverso entre o começo de 2008 e o final de 2017 no mundo, em números absolutos, figuramos com 1.071 assassinatos, ou seja, $41 \%$ do total. ${ }^{31} \mathrm{~A}$ cada 28 horas um LGBT é morto, sendo todos esses dados subnotificados, pois, como não temos uma lei anti-homofobia, o crime pode ser atestado como um delito qualquer. ${ }^{32}$

Os casos aqui retratados nem de longe representam o esquema perverso ao qual a população LGBT é submetida. Os crimes são cruéis, as vitimas são assassinadas a facadas, com muitas facadas, os tiros não são poucos. O requinte de crueldade vai desde tiros no olho, na boca, cortamse o pênis das vítimas e lhes introduzem no ânus objetos pontiagudos. Há que se falar, portanto, em crimes de ódio, duplamente agressivos porque não há sequer legislação em que se aportar.

Conforme pesquisa apresentada em 2009 pelo Ministério da Educação (MEC) e pelo Instituto Nacional de Estudos e Pesquisas Educacionais (INEP), a distância social que se guarda em relação a pessoas homossexuais, ou seja, o desejo de não se ter contato com estes sujeitos, foi a que apresentou o maior valor para o índice percentual, com 72\% (BRASIL, 2009). De cada 100 sujeitos que responderam à pesquisa, que fora realizada com servidoras/es da educação e estudantes, mais de 70 pessoas não querem ter contato com homoafetivos.

Como consequência do isolamento e das agressões às quais são submetidos os sujeitos dissidentes das normas de gênero, cerca de 30\% das diferenças de pontuação observadas na Prova Brasil entre as escolas pesquisadas foram explicadas por diferenças nos niveis de preconceito ou discriminação. O que estes dados nos indicam? Há correlação direta entre práticas discriminatórias e preconceituosas, as quais empobrecem o espaço escolar como lugar para a aprendizagem. Quanto maior o indicativo de atitudes preconceituosas entre os alunos, mais baixos são os resultados nas avaliações de matemática e português da Prova Brasil 2007 (BRASIL, 2009).

Cruel também tem sido o que ocorre dentro de universidades. Em 2010, no jornal estudantil da Faculdade de Farmácia da Universidade de São Paulo (USP), O parasita, foi veiculada publicação que encorajava os alunos a lançar excrementos humanos em estudantes LGBT em troca de entradas para uma festa.

Lance-merdas (sic) e Brega será na Faixa Ultimamente nossa gloriosa faculdade vem sendo palco de cenas totalmente inadmissiveis. Ano passado, tivemos o famoso episódio em que dois viadinhos trocaram beijos em uma festa no porão de med. Como se já não bastasse, um deles trajava uma camiseta da Atlética. Porra, manchar o nome de uma instituição da nossa faculdade em território dos médicos não pode ser tolerado. Na última festa dos bixos, os mesmos viadinhos citados acima, aprontaram uma pior ainda. Os seres se trancaram em uma cabine do banheiro, enquanto se ouviam dizeres do tipo "Ai, tira a mão daí." Se as coisas continuarem assim, nossa faculdade vai virar uma ECA. Para retornar a ordem na nossa querida Farmácia, O Parasita lança um desafio, jogue merda em um viado, que você receberá, totalmente grátis, um convite de luxo para a Festa Brega 2010. Contamos com a colaboração de todos (JORNAL DO CAMPUS, 2010).33

Que nos traz o jornal universitário O Parasita? A incitação ao ódio, o desprezo, a abjeção. Convoca os estudantes a lançarem merda sobre os "viadinhos" - no diminutivo - "seres" que se trancam em cabine de banheiro. Conclama a delimitar territórios: estamos na Faculdade de Enfermagem e não na Escola de Comunicação e Artes (ECA). Fazem as tratativas do "eu" (civilizado,

\footnotetext{
31 Ciro Gomes ignora homicidios ao afirmar que o brasileiro convive 'numa boa' com LGBTs. Aos Fatos. 13 nov. 2018. Disponivel em: https:// aosfatos.org/noticias/ciro-gomes-ignora-homicidios-ao-afirmar-que-brasileiro-convive-numa-boa-com-lgbts/. Acesso em: 20 maio 2019. 32 Dados coletados em relatórios do Grupo Gay da Bahia (GGB), a mais antiga associação de defesa dos direitos humanos dos homossexuais no Brasil. Fundado em 1980, ocupa desde 1995 a Secretaria de Direitos Humanos da Associação Brasileira de Gays, Lésbicas, Travestis, Transexuais e Intersexos - ABGLT, e desde 1998 a Secretaria de Saúde. Há mais de 30 anos coleta dados sobre assassinatos de homossexuais e transgêneros no País. Somente em 2016, o Grupo Gay da Bahia - GGB - contabilizou 373 mortes de LGBT no Brasil, 173 gays, 10 lésbicas, 4 bissexuais, 144 transexuais e travestis. Entidade. QUEM Somos. Banco de Dados. Hemeroteca Digital. Disponivel em: https://homofobiamata.wordpress.com/quemsomos-2/. Acesso em: 20 maio 2019.

33 Rodas teme ser autoritário ao combater homofobia. Jornal do Campus. 20 mai. 2010. Disponivel em: http://www.jornaldocampus.usp. br/index.php/2010/05/rodas-teme-ser-autoritario-ao-combater-homofobia/. Acesso em: 20 ago. 2019.
} 
hétero, masculino) e do "outro" (animal, viadinho, feminino), revitalizando discursos misóginos, sexistas, homofóbicos e xenófobos. Estes "viadinhos" deveriam ser agredidos porque estariam "manchando" a instituição que não deveria tolerar tal atitude e sim prezar pela "ordem na nossa querida farmácia".

A ordem é o sonho da pureza que "em seus frenéticos esforços de separar, confinar, exilar ou destruir os estranhos, comparam os objetos de suas diligências aos animas nocivos e às bactérias" (BAUMAN, 1998, p. 19). O "viadinho" produz uma nódoa, ele mancha o nome de uma instituição segundo O Parasita. Está ligado aos banheiros e à sexualidade que ali se desenvolve; deve ser impedido de beijos, carinhos, afetos em público, logo o desafio: jogue merda em um viado.

O desejo de eliminar o outro negativo também ocorreu outras vezes na maior universidade brasileira. O Centro Acadêmico da Faculdade de Direito (USP) propagou em 2005 a seguinte frase "Bons tempos em que [...] a Aids restringia-se à África e a certos ânus homossexuais" (JORNAL DO CAMPUS, 2010). O jornal daquele centro também sugeriu que camisetas fossem pintadas com a frase "Homossexualismo é doença, Aids é a cura". Em 2008, durante uma festa no Centro Acadêmico da Faculdade de Medicina Veterinária e Zootecnia (FMVZ), um casal gay foi retirado de cima do palco onde se beijavam. ${ }^{34}$

As agressões são constantes nas universidades brasileiras, conforme se verifica na pesquisa de Thiago Mendes (2012). Estudando particularmente a Universidade de Brasília, percebeu que a homofobia praticada por grupos de pessoas é (i) frequente; (ii) uma organização, muito similar à de grupos neonazistas; (ii) acolhida na universidade por meio de seu silenciamento, haja vista a inexistência de políticas públicas em defesa da diversidade sexual e de gênero na UnB. Essas manifestações discriminatórias desenvolvem seu ambiente na educação fundamental e, por falta de enfrentamento, desembocam e se perpetuam no Ensino Superior.

A escola tem se apresentado como local bastante crítico para um garoto sob o qual se desenvolva a marca da abjeção. Os outros sujeitos escolares poderão tê-lo como alvo cotidiano de zombaria, chacota, comentários maldosos e assédio (LOPES, 2003). Ele poderá ser tratado como "o veadinho da escola", tendo seu nome rabiscado nos banheiros, carteiras, paredes, livros didáticos (CAETANO; RANGEL, 2003).

Ao dar nomes como "veadinho da escola", ao nomear os sujeitos, a violência discursiva heterossexual permite que desloquemos nosso olhar da enunciação para o lócus e as relações de interpelação. Ali o sujeito do discurso da diferença é constituído dialogicamente, em um sistema ambivalente das estratégias de identificação. Ambivalente porque os sentidos são intercambiáveis e escorregam, além do que, apontam para cenas traduziveis e intraduziveis nas transferências de conteúdos e práticas dos sujeitos interpelados.

Sabe-se que convicções religiosas impactam em escolhas eleitorais e na forma como os governantes são vistos pela população. ${ }^{35}$ Discursos que polemizam o aborto e pontos que contrariam o evangelho podem empurrar uma decisão eleitoral para o segundo turno, como o ocorrido com a segunda campanha de Dilma Rousseff à presidência, e fazer florescer determinado candidato nas pesquisas eleitorais. ${ }^{36}$

\section{Considerações finais}

O discurso político-religioso traz consigo componentes de normatização e pedagogias da sexualidade, afinal, não se esquiva de determinar o limite entre o correto e o imoral, francamente contra o direito das mulheres decidirem sobre seu próprio corpo, contra a ampliação de direitos civis para os sujeitos das sexualidades não heteronormativas, tornando seus sujeitos em abjetos, os quais sofrerão com estigmas e agressões.

\footnotetext{
34 Rodas teme ser autoritário ao combater homofobia. Jornal do Campus. 20 maio 2010. Disponivel em: http://www.jornaldocampus usp.br/index.php/2010/05/rodas-teme-ser-autoritario-ao-combater-homofobia/. Acesso em: 20 ago. 2019

35 Vale conferir texto de Ari Pedro Oro (2003) publicado na "Revista Brasileira de Ciências Sociais".

36 Em 2010, o tema do aborto já aparecia como um "divisor de águas" entre os candidatos à presidência. Sobre este assunto, deve-se conferir pesquisa de Naara Luna (2014).
} 
Tratados por meio de um conjunto de emoções negativas (nojo, aversão, ódio, desconfiança, desprezo, medo, desconforto) que inferiorizam aqueles que se quer excluir do humano, estigmatizando suas características corporais e psiquicas, dando-lhes ares de animalidade e de aberração, os abjetos são compelidos a uma vida precária e despotencializada, cuja fragilidade os leva a desconfiar de si, a se agredir, negar-se, em um longo e complexo processo de elaboração de uma identidade homossexual masculina, perpassada por uma série de negociações, para dizer o mínimo, constrangedoras.

A abjeção decalca marcas que parecem convidar à agressão física e psíquica, pois, segundo Butler (2017, p 15), há uma relação entre a vulnerabilidade de certos grupos e o desejo de destruí-los. A violência à qual os desviantes da norma estão expostos tem a ver com uma interpelação discursiva que dá nome às coisas e às pessoas. Sujeitos cujas sexualidades são desviantes são submetidos a um discurso, suas vontades e desejos são regulados, privações lhes são impostas e se inaugura uma alteridade cativa e repreendida, sob o signo de um heteroterrorismo, a saber, a reiteração cotidiana de agressões verbais e físicas. Ora, "desde que nascemos, somos submetidos diariamente a um massacre: 'Comporte-se como menina, feche as pernas, seja homem, menino não chora'" (BENTO, 2017, p. 198).

A produção da heterossexualidade é um projeto diário e violento, cujo nome não se deve ser mitigado. Nada de bullying, trata-se do heteroterrorismo em ação, um projeto de inculcação de regras e normas, viabilizado pelo discurso político dominante, cristão e evangélico, o qual tem lutado para impedir o avanço de políticas públicas e se esforçado para formar subjetividades sexuais e de gênero, via assimilação, silenciamento e invisibilidade do outro-abjeto. Eles combatem a garantia do respeito à livre orientação sexual e à identidade de gênero, a garantia dos direitos das mulheres para o estabelecimento das condições necessárias para sua plena cidadania, legando a abjeção a corpos dissonantes. Estão bem distantes de considerar o aborto como tema de saúde pública, com a garantia do acesso aos serviços de saúde em um país verdadeiramente laico.

O reforço à heterossexualidade compulsória é manietado por meio de restrições que constituem as sexualidades e que funcionam de modo duplo: por um lado, as restrições e as normas produzem corpos inteligiveis - aqueles que não constrangem a relação esperada e supostamente coerente entre sexo, gênero, prática sexual e desejo -, mas por outro lado, geram todo um domínio de corpos que não devem ser pensados, que não devem ganhar importância, sendo tratados como abjetos.

Se, por um lado, é forçoso admitir avanços em relação a direitos homoafetivos, promovidos, especialmente, a partir do início dos anos 2000 , por outro lado, determinados grupos se esforçam para manter o status quo e a visão "biológica dos sexos". Por meio de seu discurso visam naturalizar e assegurar "o monopólio da normalidade à heterossexualidade", fomentando "o desdém em relação àquelas e àqueles que se afastam do modelo de referência" (BORRILLO, 2010, p. 23). As igrejas que têm reservado para si o direito de "proteger" a familia, por outro lado, têm colaborado com o acirramento de agressões e fortalecimento do ódio.

Não se pode esquecer que, os discursos político-religiosos fazem parte da trama do discurso heteronormativo, a produzir sujeição e subjetivação. À medida que constrange as potencialidades do desejo, reconhecimento e da sexualidade, exerce poder - um biopoder subjetivante - sobre os corpos dos sujeitos empobrecendo o tecido relacional e precarizando outros modos de vida.

\section{Referências}

BARTHES, Roland. O grau zero da escrita. São Paulo: Martins Fontes, 2004

BAUMAN, Zygmunt. O mal-estar da pós-modernidade. Rio de Janeiro: Jorge Zahar Ed., 1998.

BENTO, Berenice. Transviad@s: gênero, sexualidade e direitos humanos. Salvador: EdUfba, 2017. 
BORILLO, Daniel. Homofobia: História e crítica de um preconceito. Tradução de Guilherme João de Freitas Teixeira. Belo Horizonte: Autêntica, 2010.

BUTLER, Judith. Quadros de guerra: Quando a vida é passivel de luto? Rio de Janeiro: Civilização Brasileira, 2017.

BUTLER, Judith. Problemas de Gênero: feminismo e subversão da identidade. Rio de Janeiro: Civilização Brasileira, 2016.

CAETANO, Márcio. RANGEL, Mary. Os excluídos das representações da exclusão. I CONFERÊNCIA BRASILEIRA SOBRE REPRESENTAÇÕES SOCIAIS. Uerj, Rio de Janeiro, 2003.

COLLING, Leandro. Mais visiveis e mais heteronormativos: a performatividade de gênero das personagens não-heterossexuais nas telenovelas da Rede Globo. In: COLLING, Leandro; THÜRLER, Djalma (org.). Estudos e Politicas dos Cus. Salvador: Edufba, 2013.

DERRIDA, Jacques. Posições. Belo Horizonte: Autêntica, 2001.

FOUCAULT, Michel. A ordem do discurso. São Paulo: Edições Loyola, 2012.

FOUCAULT, Michel. Ditos e Escritos IX: genealogia da ética, subjetividade e sexualidade. Trad. Abner Chiquieri. Rio de Janeiro: Forense Universitária, 2010.

FOUCAULT, Michel. História da Sexualidade: a vontade de saber. São Paulo: Graal, 1988. v. 1.

LEONEL, Guilherme Guimarães. Campo religioso brasileiro na contemporaneidade: continuidades, descontinuidades, transformações e novos ângulos de análise. Interseções, Rio de Janeiro, v. 12 n. 2, p. 382-407, dez. 2010.

LOPES, Denilson. Post-gay, teoria queer e cultura contemporânea. Palestra. Grupo de Estudos e Pesquisas "Violência, Racismo e Midia: representações sociais e discursos midiáticos". Brasília, 2003.

LOURO, Guacira Lopes. Um corpo estranho: Ensaio sobre sexualidade e teoria queer. Belo Horizonte: Autêntica, 2004.

LUNA, Naara. A controvérsia do aborto e a imprensa na campanha eleitoral de 2010. Cad. CRH, Salvador, v. 27, n. 71, p. 367-391, ago. 2014. https://doi. org/10.1590/S0103-49792014000200010

MENDES, Marília Silva Martins. Manifestações do Conservadorismo e do Fascismo no Brasil contemporâneo: análise de propagandas políticas. Dissertação (Mestrado em Psicologia), Programa de Pós- graduação em Psicologia, Instituto de Psicologia: Universidade de São Paulo, São Paulo, 2018.

MENDES, Thiago Meneses de Castro. A homofobia na Universidade de Brasilia: discriminação, expressões e representações entre estudantes. Monografia (Bacharelado em Serviço Social), Universidade de Brasilia, Brasilia, Distrito Federal, 2012.

MOTT, Luiz. A igreja e a questão homossexual no Brasil. Mandrágora, São Bernardo do Campo, n. 5, 1999.
NOVAES, Regina. Errantes do novo milênio: salmos e versículos bíblicos no espaço público. In: BIRMAN, Patrícia; LEITE, Márcia (org.). Religião e espaço público. São Paulo: Attar, 2003

OLIVEIRA, Carlyle Tadeu Falcão de; MARTINS, Paulo Emílio Matos. A Hospitalidade e Cordialidade Brasileira: o Brasil percebido por estrangeiros. Turismo em Análise, USP, v. 20, n. 2, ago. 2009. https://doi. org/10.11606/issn.1984-4867.v20i2p196-209

ORO, Ari Pedro. A política da Igreja Universal e seus reflexos nos campos religioso e político brasileiros. Revista Brasileira de Ciências Sociais, ANPOCS - Associação Nacional de Pós-Graduação e Pesquisa em Ciências Sociais, São Paulo, v. 18, n. 53, out. 2003.

SANTAELLA, Lúcia. A assinatura das coisas. Rio de Janeiro: Imago, 1992.

SANTOS, Maria Iris Abreu. Experiência religiosa e teologia da prosperidade entre fiéis da Igreja Universal. Dissertação (Mestrado). Universidade Federal do Ceará, Centro de Humanidades, Fortaleza, 2015.

\section{Alexandre de Oliveira Fernandes}

Doutor em Ciência da Literatura pela Universidade Federal do Rio de Janeiro (UFRJ), Rio de Janeiro, RJ, Brasil. Professor do Instituto Federal de Educação da Bahia (IFBA/Porto Seguro). Professor permanente no Programa de Pós-Graduação em Relações Étnicas e Contemporaneidade - PPGREC/UESB/Jequié. Professor Permanente no Programa de Pós-Graduação em Ensino e Educação das Relações Étnico-Raciais da Universidade Federal do Sul da Bahia - UFSB.

\section{Luciano Fernandes de Souza}

Especialista em Politicas Públicas e Contextos Educativos pelas Faculdades Nossa Senhora de Lourdes (FNSL/Porto Seguro, BA, Brasil). Mestre em Educação pela Universidade Lusófona de Portugal (ULHT, Lisboa, Portugal). Defendeu dissertação intitulada, "Consentida, ensinada, resistida: discursos de egressos não heteronormativos sobre a homofobia na escola".

\section{Endereço para correspondência}

Alexandre de Oliveira Fernandes

Instituto Federal de Educação da Bahia - IFBA

Rod. $\mathrm{Br} 367 \mathrm{Km} 57,5$

Fontana I, 45810-000

Porto Seguro, BA, Brasil

Luciano Fernandes de Souza

Av. Navegantes, 244

Centro, 45810-000

Porto Seguro, BA, Brasil 